\title{
Preliminary Study by Environmental Indicator Measurements of Sediments in a Mangrove Forest in Ilha Grande Bay, Rio de Janeiro, Southeastern Brazil
}

\author{
Ana Maria A. Velho ${ }^{1}$, Claudia A. F. Aiub ${ }^{1,2^{*}}$, José L. Mazzei ${ }^{1}$, Sérgio M. Corrêa ${ }^{3}$, \\ Mário L. G. Soares ${ }^{4}$, Israel Felzenszwalb ${ }^{1}$ \\ ${ }^{1}$ Department of Biophysics and Biometry, Institute of Biology Roberto Alcantara Gomes, Rio de Janeiro State University, Vila Isabel, \\ Brazil; ${ }^{2}$ Departamento de Genética e Biologia Molecular, Instituto Biomédico, Universidade Federal do Estado do Rio de Janeiro, \\ Centro, Brazil; ${ }^{3}$ Department of Environmental Chemistry, Institute of Chemistry, Rio de Janeiro State University, Resende, Brazil; \\ ${ }^{4}$ Center for Research on Mangroves, Institute of Oceanography, Rio de Janeiro State University, Maracanã, Brazil. \\ Email: *aiub@hotmail.com
}

Received May $9^{\text {th }}, 2012$; revised June $11^{\text {th }}, 2012$; accepted July $13^{\text {th }}, 2012$

\begin{abstract}
Mangroves perform essential functions in biological cycles and are protected by law in Brazil. However, they are being degraded above their support limit, leading to a reduction in the areas around the world. The area investigated in the present study is a potentially unpolluted mangrove ecosystem in the south of Rio de Janeiro State, Brazil. The aim of this work was to investigate the presence of metals and polycyclic aromatic hydrocarbons (PAHs) in mangrove sediment and to correlate them with mutagenic and genotoxic activity. Four seasonal samplings undertaken between 2009 and 2010 at five sites were analyzed. Dichloromethane extracts were obtained under sonication and subjected to mutagenicity assays using Salmonella microsuspension. Metal $(\mathrm{Cd}, \mathrm{Cr}, \mathrm{Cu}, \mathrm{Ni}$ and $\mathrm{Pb})$ contents were determined by atomic absorption spectrometry, while the quantification of PAHs was performed by gas chromatography-mass spectrometry. Goniopsis cruentata hemocytes were used to assess potential genotoxic damage (Micronucleus assay). The absence of mutagenicity was observed for all samples using Salmonella typhimurium strains TA97, TA98, TA100 and TA102, in the absence and presence of an exogenous mammalian metabolizing system. Among the metals, $\mathrm{Cd}$ and $\mathrm{Cu}$ were detected in autumn at values exceeding the threshold effect level and below the probable effect level. Benzo[a] pyrene was detected at levels above the threshold at one site, where small effects could be observed in the biota. Significant differences in the micronucleated cells observed suggest DNA damage had been induced by the PAHs identified.
\end{abstract}

Keywords: Sediments; Mutagenicity; Goniopsis cruentata; Genotoxicity; Polycyclic Aromatic Hydrocarbons (PAHs); Metals

\section{Introduction}

The characterization of unpolluted or slightly impacted areas is necessary for monitoring the environment, preventing impacts and implementing solutions where the remediation of environmental accidents is required. In this context, mangrove areas are important as they provide a barrier against pollutants and perform unique ecological roles, representing direct economic value. However, due to fluctuations in chemical and physical dynamics and geomorphological conditions, the interpretation of the effects of disturbances on biotic communities is a complex task [1].

Sediment has been identified as an important suitable

"Corresponding author. compartment for the study of metals and polycyclic aromatic hydrocarbons (PAHs) [2]. Among the substances that may be pollutants (USEPA 2010), PAHs result mainly from the burning of fuels entering the aquatic environment mainly through atmospheric deposition, urban runoff, municipal effluents, industrial wastewater, and oil spill increasingly common. They have a low rate of degradation in the environment and are a widely used class of geochemical markers with known toxic and mutagenic potential, or carcinogenic properties [3].

Since sediments are transported by rivers to other bodies of water or the sea, analyses of sediments in different settings from the same region are useful for tracking and managing the control of contaminant dispersal routes [4]. Most of the contaminants that enter aquatic 
systems accumulate in the bottom sediment. As such, sediments are the ultimate destination for all processes occurring in the air, water and soil, with the ability to accumulate low concentrations of the elements present in water [5].

Background values for marine sediments have been established by the National Oceanographic and Atmospheric Administration (NOAA, USA) and are referenced as the threshold effect level (TEL) and the probable effect level (PEL) [6]. In Brazil, the quality criteria for sediments to be dredged (National Council of the Environment-CONAMA Resolution 344/2004) [7] and for soils (CONAMA 420/2009) [8] exclude cover for marine sediments. Beyond this restriction, no criteria or guiding values have been established for the quality of marine sediments, although the marine domain is increasingly exploited and influenced by harbor activities, oil exploration, industrial activities and oil refining.

A mangrove located in Saco do Mamanguá harbor and part of Juatinga Ecological Reserve [9], which is a conservation area (APA Cairuçu), is an example of a preserved mangrove that is susceptible to impacts. Saco do Mamanguá is on the mainland of Brazil in Ilha Grande bay, which lies between São Paulo and Rio de Janeiro, areas of high population density that have been widely impacted by industrial, tourist and agricultural activities. About 2000 people live in Saco do Mamanguá, but in the summer months it receives as many as 20,000 visitors. During this season, the increased volumes of sewage, garbage, boats and cars in adjacent areas can induce environmental impacts. These activities may lead to an accumulation of metals and PAHs, resulting in rising toxic effects in individuals or populations in the medium and long term. It is known that these substances can cause deleterious mutations, and thereby increase the risk of neoplasia [10]. The absence of studies that consider these effects in the mangroves around the world justifies undertaking predictive studies in Saco do Mamanguá.

The aim of this preliminary study was to obtain qunatitative analysis of metals and PAHs in Saco do Mamanguá and to evaluate the mutagenic activity of sediment organic extracts and genotoxic damage in native crabs. The determination of these pollutant levels and investigation of the associated damage may contribute towards improving the reference indicators for the environment in the Ilha Grande bay mangroves. These data will be usefull for the local communities, management teams and government for registration and comparison with later data. For this purpose, the samplings sites were also characterized for their physicochemical and granulometric properties. A short-term Salmonella/microsome bioassay, which is recommended for in vitro predictive testing by national-CONSEMA 2006 [11] and international assessments in environmental samples-USEPA 1998 [12] and as a micronucleus assay using an in vivo model [13] were used in the present work.

\section{Materials and Methods}

\subsection{Study Area and Experimental Design}

The area is located in the municipality of Parati, between latitude $23^{\circ} 17^{\prime} \mathrm{S}$ and $23^{\circ} 18^{\prime} \mathrm{S}$ and meridian $44^{\circ} 38^{\prime} \mathrm{W}$, on the southern coast of Rio de Janeiro state (Figure 1(a)). Samples of surface sediments $(5-15 \mathrm{~cm})$ were collected in triplicate manually from the five sites in the Saco do Mamanguá mangroves (M1 - M5; Figure 1(b)) using suitable, uncontaminated equipment, and stored, all in accordance with internationally recognized standard procedures-USEPA 2001 [14].

Quality control were observed due to minimize interferences, especially in localities potentially clean. We used uncontaminated amber glass vials and stainless steel spatulas and kept refrigerated until they reach the laboratory where they were frozen.

Adult male crabs (Goniopsis cruentata) were collected manually using gloves and hand-held fishing nets, having first received licenses for this activity from the relevant state and federal environmental agencies. The red-clawed mangrove tree crab (G. cruentata) was identified in the field by its typical morphological features [15]. Only one animal was collected per point, totaling five individuals per season. The protocol used complied with the Ethical Principles in Animal Research adopted by the Brazilian College of Animal Experimentation (COBEA) and was approved by the Ethics Committee for the Care and Use of Experimental Animals from the Roberto Alcantara Gomes Institute of Biology (CEA/014/2010)-Rio de Janeiro State University (UERJ).

Four season samplings were undertaken between October 2009 and December 2010, named spring I, summer, autumn and spring II. The campaigns and their respective types of samples and analysis are summarized in Table 1.

Adult male crabs (Goniopsis cruentata) were collected manually using gloves and hand-held fishing nets, having first received licenses for this activity from the relevant state and federal environmental agencies. The red-clawed mangrove tree crab (G. cruentata) was identified in the field by its typical morphological features [15]. Only one animal was collected per point, totaling five individuals per season. The protocol used complied with the Ethical Principles in Animal Research adopted by the Brazilian College of Animal Experimentation (COBEA) and was approved by the Ethics Committee for the Care and Use of Experimental Animals from the Roberto Alcantara Gomes Institute of Biology (CEA/014/2010) - Rio de Janeiro State University (UERJ). 

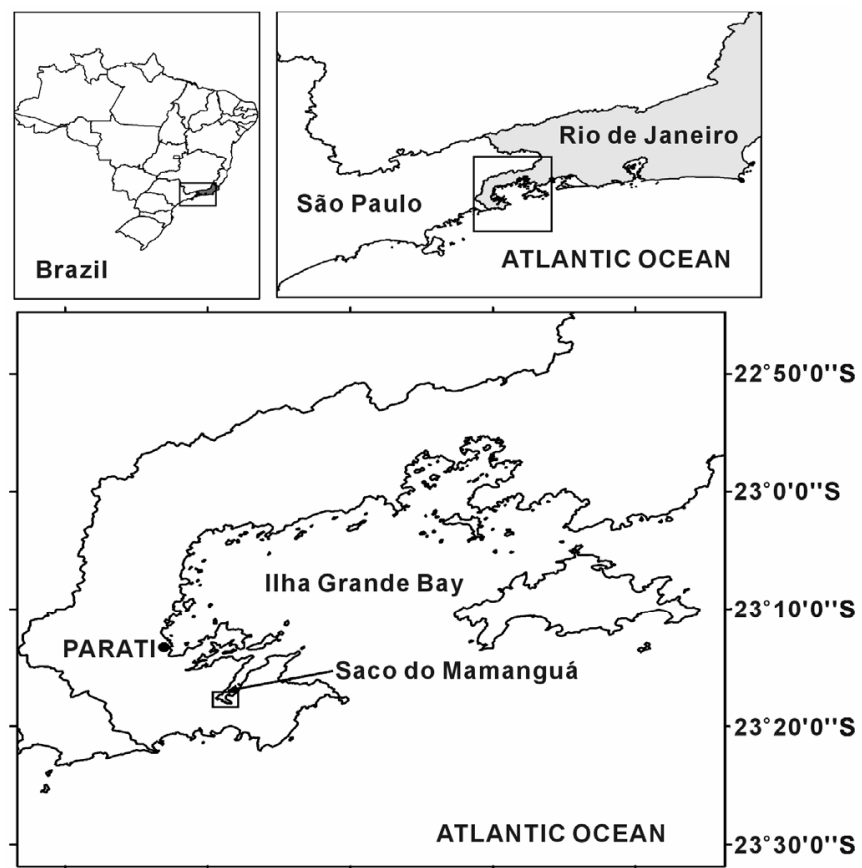

$44^{\circ} 50^{\prime} 0^{\prime} \mathrm{W} 44^{\circ} 40^{\prime} 0^{\prime \prime} \mathrm{W} 44^{\circ} 30^{\prime} 0^{\prime} \mathrm{W} 44^{\circ} 20^{\prime} 0^{\prime \prime} \mathrm{W} 44^{\circ} 10^{\prime} 0^{\prime \prime} \mathrm{W}$

(a)

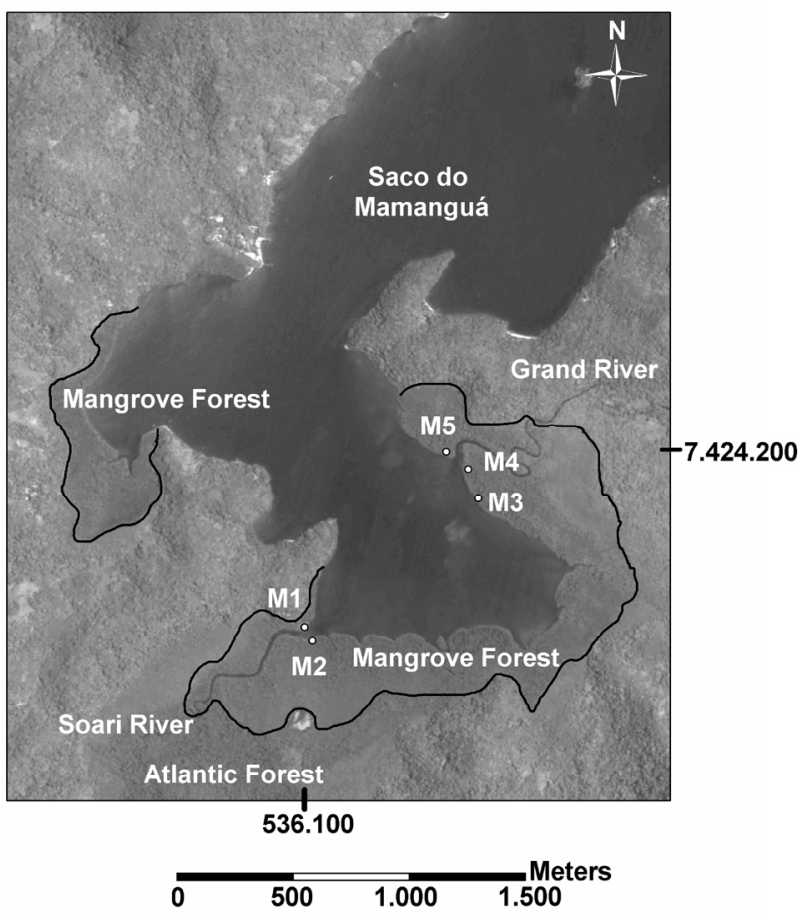

(b)

Figure 1. (a) Location map of the study area; (b) M1-M5, represents sampling sites in the Saco do Mamanguá mangrove forests.

Table 1. Sample studies performed in Saco do Mamanguá mangrove forest (Rio de Janeiro, Brazil).

\begin{tabular}{ccccc}
\hline Sampling & Period & Sample Types & Physicochemical Measurements & Analyses \\
\hline Spring I & October/2009 & Sediment, Crab & $\mathrm{pH}$ & Mutagenicity, Genotoxicity, PAHs \\
Summer & March/2010 & Sediment, Crab & $\mathrm{pH}$, Temperature, Eh & Mutagenicity, Genotoxicity, PAHs \\
Autumn & July/2010 & Sediment & $\mathrm{pH}$, Temperature, Eh & Mutagenicity, Metals, PAHs \\
Spring II & December/2010 & Sediment, Crab & $\mathrm{pH}$, Temperature, Eh & Mutagenicity, Genotoxicity, Metals, PAHs \\
\hline
\end{tabular}

Four season samplings were undertaken between October 2009 and December 2010, named spring I, summer, autumn and spring II. The campaigns and their respective types of samples and analysis are summarized in Table $\mathbf{1 .}$

\subsection{Grain Size Analysis}

The grain size analysis was performed in the Laboratory of Geological Oceanography/UERJ, according to Suguio (1973) [16]. Fractions of the sediments were classified as sand, silt and clay, giving a basic characterization of the site.

\subsection{In Situ Physicochemical Measurements}

Sediment $\mathrm{pH}$ and temperature were determined as described by Burton et al. (2005) [16] using a portable meter Q400AM (Quimis, Brazil), by directly inserting calibrated electrodes into the sediments at the sampling sites. The Eh (redox potential) of the sediment was measured in the same way using a combined platinum electrode with an $\mathrm{Ag} / \mathrm{AgCl} / 3 \mathrm{M} \mathrm{KCl}$ reference electrode. The measurements were corrected to the standard hydrogen electrode by calculating against the standard potential of the reference electrode.

\subsection{Sediment Organic Extracts}

The extraction of PAHs was carried out according to Tagliari et al. (2004) [17], with some modifications. A 30 -g aliquot of wet-dried sediment was sonicated by in four $5 \mathrm{~min}$ cycles in dichloromethane (Tedia, HPLC grade) (100 mL per cycle). The organic extracts were first filtered through glass wool (Reagen, Brazil) and sodium sulfate (Proquimios, analytical grade) and further through Celite 545 (Tedia, Brazil) and sodium sulfate. The filtrates were concentrated in a rotary evaporator (Fisatom) $\left(40^{\circ} \mathrm{C}\right)$ and the final volumes were adjusted at $15.0 \mathrm{~mL}$. These filtrates were stored at $-20^{\circ} \mathrm{C}$ for up to 
30 days. Immediately before the mutagenicity analysis, the extracts were evaporated under nitrogen and resuspended in dimethylsulfoxide (DMSO, analytical grade).

\subsection{Chemical Analysis-Metals and PAHs}

For the metal $(\mathrm{Cd}, \mathrm{Cr}, \mathrm{Cu}, \mathrm{Ni}$ and $\mathrm{Pb})$ analysis, the Aqua Regia Extraction Protocol was based upon the BCR-701 reference procedure from standards, measurements and testing programme [18], which determines traces in sediments. Samples were wet-sieved through a nylon $63 \mu \mathrm{m}$ sieve and dried at $50^{\circ} \mathrm{C}$ until constant weight. $1 \mathrm{~g}$ sediment was extracted in duplicate with $9.3 \mathrm{~mL}$ Aqua Regia (room temperature for $16 \mathrm{~h}$, followed by heating for $2 \mathrm{~h}$ ) and blanks were also prepared without sediment. Quantification of $\mathrm{Cd}, \mathrm{Cr}, \mathrm{Cu}, \mathrm{Ni}$ and $\mathrm{Pb}$ was performed by atomic absorption spectrophotometry using an AAS-240 (Varian) with air-acetylene flame and graphite tube atomizer.

Sixteen PAHs that have been established as priority by the EPA were quantified by gas chromatography/mass spectrometry (GC/MS). The identification and quantification of the PAHs was performed using a Varian system consisting of a gas chromatograph (450-GC), with a split/ splitless injector $1177 \mathrm{~S} / \mathrm{SL}$ ( $\mathrm{kept}$ at $300^{\circ} \mathrm{C}$ ) coupled to the mass spectrometer detector MS 220. The ion trap $\left(250^{\circ} \mathrm{C}\right)$, manifold $\left(280^{\circ} \mathrm{C}\right)$ and transfer line $\left(280^{\circ} \mathrm{C}\right)$ were maintained at constant temperatures.

PAHs were identified by mass similarity and by the retention time of the components in a commercial standard kit (Supelco, PAH610-S). Quantification was based on five calibration points, which were constructed from each standard for all target analytes ranging from 10 to $250 \mathrm{pg} / \mu \mathrm{L}$. Injections $(1.0 \mu \mathrm{L})$ were splitless, with the split opened after $0.5 \mathrm{~min}$, and helium was used as the carrier gas. A VF-5MS column $(30 \mathrm{~m} \times 0.25 \mathrm{~mm} \times 0.25$ $\mu \mathrm{m})$ was employed. The column and septum purge flows were set at 1.6 and $3 \mathrm{~mL} \cdot \mathrm{min}^{-1}$, respectively. The oven temperature program was as follows: $70^{\circ} \mathrm{C}$ for $4 \mathrm{~min}$ and $70^{\circ} \mathrm{C}-300^{\circ} \mathrm{C}$ at $10^{\circ} \mathrm{C} \cdot \mathrm{min}^{-1}$. The limits of quantification were determined from the minimum point in the calibration curves. Limits of detection were determined from PAH concentrations which resulted in a signal-to-noise ratio of 3:1. Content values were calculated for the weight of sediment with the blank discounted. Blanks were prepared in the absence of sediment, and the resulting extracts were analyzed identically.

\subsection{Salmonella/Microsome Assay}

The mutagenicity of sediment organic extract was evaluated using the Salmonella microsuspension bioassay with modifications [19] using the TA97, TA98, TA100 and TA102 strains of S. typhimurium. Aliquots of $100 \mu \mathrm{L}$ bacterial culture $\left(10^{10}\right.$ cels $\left./ \mathrm{mL}\right)$ and $100 \mu \mathrm{L}$ metabolic activation mixture (S9 mix) or phosphate buffer $(0.2 \mathrm{M}$, $\mathrm{pH}$ 7.4) were pre-incubated with extract concentrations (2.5, 10, 40 and $80 \mathrm{mg}$ sediment/plate). The $\mathrm{S} 9 \mathrm{mix}$ was prepared from a mammalian microsomal fraction S9 (Moltox, USA), activated by the polychlorinated biphenyl mixture Aroclor 1254, added with cofactors [20].

DMSO $(5 \mu \mathrm{L})$ was used as a negative control. The positive control for strains without exogenous metabolism (-S9) was 4-nitroquinoline-1-oxide (CAS 76082-65$0), 1 \mu \mathrm{g} /$ plate for TA97 and TA98, sodium azide (CAS 26628-22-8), $10 \mu \mathrm{g} /$ plate for TA100 and mitomycin C (CAS 50-07-7), $10 \mu \mathrm{g} / \mathrm{plate}$ for TA102. The positive control in the assays with $\mathrm{S} 9$ mix was 2-aminoanthracene (CAS 613-13-8), $5 \mu \mathrm{g} / \mathrm{plate}$ for TA97, TA98, TA100 and TA102.

Samples were pre-incubated for $90 \mathrm{~min}$, light protected, at $37^{\circ} \mathrm{C}$, without shaking. After this period, $2 \mathrm{~mL}$ top-agar $(0.7 \%$ agar, $0.6 \% \mathrm{NaCl}, 50 \mu \mathrm{M}$ L-histidine, 50 $\mu \mathrm{M}$ biotin, $\mathrm{pH} 7.4,45^{\circ} \mathrm{C}$ ) was added to the test tube and poured into a Petri dish containing minimal agar (1.5\% agar, Vogel-Bonner E medium containing $2 \%$ glucose). Mutagenicity was determined by counting the revertant colonies induced after incubation for $72 \mathrm{~h}$.

Cytotoxicity was performed by suitable dilution in $\mathrm{NaCl} 0.9 \%(\mathrm{w} / \mathrm{v})$ and a final suspension was plated on nutrient agar $(1.5 \%$ agar, $0.8 \%$ Bacto nutrient broth (Difco), $0.5 \% \mathrm{NaCl}$ ). The plates were then incubated at $37^{\circ} \mathrm{C}$ for $24 \mathrm{~h}$ and the colonies counted. All the experiments were done in triplicate. Cytotoxicity was considered positive when there were $60 \%$ fewer colonies than observed in the negative control.

Samples were considered mutagenic when the number of revertant colonies from the induced mutation $(\mathrm{MI}) \geq 2$, which is a significant response for the one-way analysis of variance (ANOVA, $\mathrm{P} \leq 0.05$ ) and no cytotoxicity was observed [21]. Correlations were calculated by Pearson's correlation coefficients.

\subsection{Micronucleus Determination}

Hemolymph was removed from the crabs' cheliped with a syringe $(21 \mathrm{G} 1 / 2$ " $0.45 \times 13)$. The hemolymph was transferred to a microscope slide, previously covered with poly-lysine, dried at room temperature and then fixed with Carnoy solution (methanol/acetic acid 3:1) for $20 \mathrm{~min}$. The dye used was $3 \% \mathrm{v} / \mathrm{v}$ Giemsa solution for 20 min, and the excess was removed by washing with deionized water. By examining the slides using light microscopy $(500 \times$ or $1000 \times), 1000$ hemocytes per animal were counted and the number of micronucleus $(\mathrm{MN})$ cells were recorded [22]. The samples were compared to each other using ANOVA and Tukey's test. A null hypothesis test was run to compare average values with reported criteria for positive results. 


\section{Results and Discussion}

\subsection{Grain Size Characterization}

Table 2 shows data obtained from the granulometric analysis of the sediment. Sites M1 to M4 had a similar composition, with $0.2 \%$ sand and $99.8 \%$ mud, which was divided into silt and clay. M5 had a lower composition of mud (84.4\%) than the other sites, probably because of its location: it is closer to the mouth of the cove, making its sediments more prone to movement (hydrodynamics).

Teixeira (2009) [23] obtained similar results in his evaluation of sediments from several creeks in Ilha Grande bay and 23 specific points along Saco do Mamanguá, reporting that this latter harbor had the highest average clay content. Particles lower than $63 \mu \mathrm{m}$ are the most important fraction for the analysis of contaminants, because their properties (e.g. large areas and high ion exchange capacity) make them effective cleaning agents for some contaminants that are discharged into aquatic systems [24].

\subsection{Physicochemical Measurements}

A description of physicochemical parameters is presented in Table 3. The $\mathrm{pH}$ range observed improves oxidizing conditions in mangrove sediments $[25,26]$. Consistent $\mathrm{pH}$ differences between sampling sites within the same season were not observed. As expected, the highest temperature averages were detected in summer, followed by spring II and autumn. The Eh values suggest that the environment was neither predominantly reducing (negative scale) nor oxidizing (positive scale). It is known that mangroves have variations in their Eh values that range from positive to negative scales in surface soil $[25,26]$. However, it is interesting to point out that M1 and M5, closest to the mouth of Saco do Mamanguá cove, had slightly more oxidizing values than the other sites. Such values are often related to higher topographies and mature mangrove forests.

\subsection{Metals and PAHs}

The chemical analysis of metals (Table 4) indicated values above TEL - $\mathrm{Cd}$ and $\mathrm{Cu}$ in autumn - but neither was above the PEL (9.6 and $270 \mathrm{mg} \cdot \mathrm{Kg}^{-1}$ sediment equivalent, respectively). The highest content of each metal was found in this season, suggesting a seasonal effect on metal content. No correlation between the metals and the physicochemical parameters was observed, but the highest contents could be related to waste from tourist activity in the summer.

As can be observed from Table 5, only the highest molecular weight PAHs were detected and quantified. The highest PAHs values were found in spring I and
Table 2. Granulometric compositions (\%) of the sediments from Saco do Mamanguá mangrove forest (Rio de Janeiro, Brazil).

\begin{tabular}{cccccc}
\hline \multirow{2}{*}{ Fraction (\%) } & \multicolumn{5}{c}{ Sites } \\
\cline { 2 - 6 } & M1 & M2 & M3 & M4 & M5 \\
\hline Sand $^{\mathrm{a}}(63 \mu \mathrm{m}-2 \mathrm{~mm})$ & 0.2 & 0.2 & 0.2 & 0.2 & 15.6 \\
Silt $^{\mathrm{a}}(2-63 \mu \mathrm{m})$ & 55.3 & 54.5 & 55.6 & 54.7 & 46.2 \\
Clay $^{\mathrm{a}}(<2 \mu \mathrm{m})$ & 44.5 & 45.3 & 44.2 & 45.1 & 38.2 \\
\hline
\end{tabular}

${ }^{\mathrm{a} C}$ Classification following criteria according to Suguio (1973).

Table 3. Physicochemical parameters obtained in situ in Saco do Mamanguá mangrove forest (Rio de Janeiro, Brazil).

\begin{tabular}{|c|c|c|c|c|}
\hline Season Sampling & Sites & $\mathrm{pH}$ & Temperature $\left({ }^{\circ} \mathrm{C}\right)$ & Eh $(\mathrm{mV})$ \\
\hline \multirow{5}{*}{ Spring I } & M1 & 6.5 & $-^{a}$ & $-{ }^{a}$ \\
\hline & M2 & 7.0 & $-^{a}$ & $-{ }^{a}$ \\
\hline & M3 & 7.0 & $-^{a}$ & $-{ }^{a}$ \\
\hline & M4 & 6.5 & $-^{a}$ & $-{ }^{a}$ \\
\hline & M5 & 6.0 & $-^{a}$ & $-{ }^{a}$ \\
\hline \multirow{5}{*}{ Summer } & M1 & 6.8 & 29.5 & 44 \\
\hline & M2 & 6.9 & 31.7 & -341 \\
\hline & M3 & 6.9 & 31.5 & -168 \\
\hline & M4 & 6.6 & 29.9 & -164 \\
\hline & M5 & 7.1 & 29.1 & 312 \\
\hline \multirow{5}{*}{ Autumn } & M1 & 7.4 & 23.4 & 93 \\
\hline & M2 & 6.7 & 23.0 & 24 \\
\hline & M3 & 6.5 & 22.4 & 128 \\
\hline & M4 & 6.1 & 22.7 & -78 \\
\hline & M5 & 6.7 & 23.2 & 173 \\
\hline \multirow{5}{*}{ Spring II } & M1 & 5.9 & 25.0 & 180 \\
\hline & M2 & 5.6 & 25.0 & 67 \\
\hline & M3 & 6.0 & 30.0 & -147 \\
\hline & M4 & 6.6 & 32.0 & 79 \\
\hline & M5 & 6.5 & 28.6 & 245 \\
\hline
\end{tabular}

${ }^{\mathrm{a}}$ Not measured.

summer, with some of the samples from M1 in both seasons yielding values above the TEL. The highest Benzo $[a]$ pyrene $(\mathrm{B}[a] \mathrm{P})$ content, found in summer, could be attributed to tourist activity, while the highest $\mathrm{PAH}$, in spring I, could derive from an occasional, unidentified event. In autumn, $\mathrm{B}[a] \mathrm{P}$ was only detected in $\mathrm{M} 1$, and no PAHs were detected in spring II. Site M1 had the highest 
Table 4. Total metal concentration in mangrove sediment samples from Saco do Mamanguá (Rio de Janeiro, Brazil).

\begin{tabular}{|c|c|c|c|c|c|}
\hline \multirow{2}{*}{ Metals } & \multicolumn{5}{|c|}{ Autumn } \\
\hline & M1 & M2 & M3 & M4 & M5 \\
\hline Cadmium & $1.6^{*}$ & 0.1 & $-{ }^{b}$ & $-{ }^{b}$ & 1.0 \\
\hline Chromium & 3.9 & 11.5 & 7.7 & 5.5 & 5.8 \\
\hline Copper & 31.7 & $66.8^{*}$ & $42.3^{*}$ & 21.6 & 1.7 \\
\hline Nickel & 16.2 & 10.3 & 6.0 & 7.5 & 12.2 \\
\hline \multirow[t]{3}{*}{ Lead } & 14.8 & 11.8 & 13.8 & 6.5 & 17.0 \\
\hline & \multicolumn{5}{|c|}{ Spring II } \\
\hline & M1 & M2 & M3 & M4 & M5 \\
\hline Cadmium & 0.5 & 0.8 & 0.8 & 0.6 & 0.2 \\
\hline Chromium & 2.1 & 3.1 & 4.3 & 6.6 & 8.7 \\
\hline Copper & 13.9 & $-{ }^{b}$ & 1.8 & 1.8 & 13.2 \\
\hline Nickel & 9.3 & 9.5 & 9.8 & 8.9 & 6.4 \\
\hline Lead & 6.5 & 10.3 & 11.5 & 9.8 & 13.3 \\
\hline
\end{tabular}

Table 5. PAH identified and quantified in the organic sediments extract from Saco do Mamanguá mangroves (Rio de Janeiro, Brazil).

\begin{tabular}{|c|c|c|c|c|c|c|}
\hline \multirow{2}{*}{$\mathbf{P A H}^{\mathrm{a}, \mathrm{b}}$} & \multirow{2}{*}{$\mathbf{L Q}^{\mathbf{c}}$} & \multicolumn{5}{|c|}{ Spring $\mathbf{I}^{\mathrm{d}}$} \\
\hline & & M1 & M2 & M3 & M4 & M5 \\
\hline Benzo $[a]$ anthracene & 0.006 & 0.07 & $-{ }^{e}$ & $-{ }^{e}$ & $-{ }^{\mathrm{e}}$ & $-{ }^{\mathrm{e}}$ \\
\hline Chrysene & 0.006 & 0.04 & $-{ }^{\mathrm{e}}$ & $-{ }^{\mathrm{e}}$ & $-{ }^{\mathrm{e}}$ & $-{ }^{\mathrm{e}}$ \\
\hline Benzo $[b]$ fluoranthene & 0.012 & 0.11 & 0.07 & $-{ }^{\mathrm{e}}$ & $-{ }^{e}$ & $-{ }^{\mathrm{e}}$ \\
\hline Benzo $[k]$ fluoranthene & 0.012 & 0.12 & 0.07 & $-{ }^{e}$ & $-{ }^{e}$ & $-{ }^{\mathrm{e}}$ \\
\hline Benzo $[a]$ pyrene & 0.012 & 0.18 & 0.12 & $-{ }^{e}$ & $-{ }^{e}$ & $-{ }^{\mathrm{e}}$ \\
\hline Indeno[1.2.3-cd]pyrene & 0.031 & 0.27 & 0.19 & 0.11 & 0.08 & $-{ }^{\mathrm{e}}$ \\
\hline $\operatorname{Dibenzo}[a . h]$ anthracene & 0.031 & $0.22^{*}$ & 0.22 & 0.06 & 0.05 & 0.06 \\
\hline \multirow[t]{2}{*}{ Benzo[g.h.i]perylene } & 0.031 & 0.34 & 0.20 & 0.07 & 0.07 & $-{ }^{\mathrm{e}}$ \\
\hline & & \multicolumn{3}{|c|}{ Summer } & \multicolumn{2}{|c|}{ Autumn } \\
\hline $\mathbf{P A H}^{\mathrm{a}, \mathrm{b}}$ & $\mathbf{L} \mathbf{Q}^{\mathbf{c}}$ & M1 & M2 & M3 & \multicolumn{2}{|c|}{ M1 } \\
\hline Benzo $[a]$ anthracene & 0.006 & $-{ }^{e}$ & $-{ }^{e}$ & $-{ }^{\mathrm{e}}$ & \multicolumn{2}{|c|}{$-{ }^{\mathrm{e}}$} \\
\hline Chrysene & 0.006 & $-{ }^{e}$ & $-{ }^{\mathrm{e}}$ & $-{ }^{e}$ & \multicolumn{2}{|c|}{$-{ }^{\mathrm{e}}$} \\
\hline Benzo $[b]$ fluoranthene & 0.012 & $-{ }^{e}$ & $-{ }^{e}$ & $-{ }^{e}$ & \multicolumn{2}{|c|}{$-{ }^{\mathrm{e}}$} \\
\hline Benzo $[k]$ fluoranthene & 0.012 & $-{ }^{\mathrm{e}}$ & $-{ }^{\mathrm{e}}$ & $-{ }^{\mathrm{e}}$ & \multicolumn{2}{|c|}{$-^{\mathrm{e}}$} \\
\hline Benzo $[a]$ pyrene & 0.012 & $0.46^{*}$ & $-{ }^{\mathrm{e}}$ & $-{ }^{\mathrm{e}}$ & \multicolumn{2}{|c|}{0.07} \\
\hline Indeno[1.2.3-cd]pyrene & 0.031 & 0.06 & $-{ }^{e}$ & $-{ }^{e}$ & \multicolumn{2}{|c|}{$-^{e}$} \\
\hline $\operatorname{Dibenzo}[a \cdot h]$ anthracene & 0.031 & $-{ }^{e}$ & $-\mathrm{e}$ & $-{ }^{e}$ & \multicolumn{2}{|c|}{$-\mathrm{e}$} \\
\hline Benzo[g.h.i]perylene & 0.031 & 0.13 & 0.09 & 0.07 & \multicolumn{2}{|c|}{$-^{\mathrm{e}}$} \\
\hline
\end{tabular}

${ }^{\mathrm{a}} \mathrm{mg} \cdot \mathrm{Kg}^{-1}$ sediment equivalent; ${ }^{\mathrm{b}}$ Unlisted PAHs were not detected (<limit of detection) in all sampling sites; ${ }^{\mathrm{c}}$ Limit of Quantification by GC/MS; for unlisted PAH LQ was $0.006 \mathrm{mg} \cdot \mathrm{Kg}^{-1}$; ${ }^{\mathrm{d}} \mathrm{PAH}$ in other season sampling and sites were not detected; 'Not detected; "Values above TEL (threshold effect level) for marine sediments $\left(0.088 \mathrm{mg} \cdot \mathrm{Kg}^{-1}\right.$ for Benzo $[a]$ pyrene, $0.006 \mathrm{mg} \cdot \mathrm{Kg}^{-1}$ for Dibenzo $[a \cdot h]$ anthracene) . 
PAH content, independently of the season. In fact, it was observed that $\mathrm{SPAH}$ in $\mathrm{M} 1>\mathrm{M} 2>(\mathrm{M} 3, \mathrm{M} 4$ and M5), in a comparison between seasonal sampling campaigns of the sites with the presence of PAHs. This feature may also be related to the local geomorphology, since M1 and M2 are both located in the southern portion of the harbor, whereas the others are on the opposite side. In fact, as M5 is more subject to hydrodynamics and has a low composition of fines, a decrease in the retention of organic compounds is to be expected.

The highest levels of toxic chemicals, both metals and nonmetals, were observed in samples from different seasons. However, it is highly likely for two or more pollutants to have been simultaneously present in the areas of the mangrove under study. $\mathrm{Cd}$ and $\mathrm{B}[a] \mathrm{P}$ were found to be above the TEL in different periods in the Saco do Mamanguá mangrove. The interaction between these substances has been identified as potentially causing genotoxic damage to the zebra mussel Dreissena polymorpha, which is considered a sentinel organism in Europe [27].

\subsection{Salmonella/Microsome Assay}

No mutagenic or cytotoxic responses were observed in any of the samples taken from any of the sites in any of the sampling campaigns, since the MI values were lower than 2 (data shown in electronic supplementary material). These results suggest that the toxic compounds could be interacting with carbonaceous matter in the sediment, reducing their mutagenicity [28] or their contents are lower than values for inducible DNA damage by addition, deletion or base pair substitution. Nevertheless, doseresponse trends in a strong positive linear relationship ( $\mathrm{r}$ $>0.8, \mathrm{P}<0.05$ ) were observed in some bioassays, the majority for TA97 in either the absence or presence of metabolic activation (M2 - M5 in spring I and M1 - M5 in autumn, respectively), suggesting that an increase of doses of sediment extract per plate could increase the MI values. The positive trend curves observed for all the points in autumn may be due to the higher levels of carcinogenic metals than in the other seasons.

In the summer, when the highest $\mathrm{B}[a] \mathrm{P}$ content was detected, significant $(\mathrm{P}<0.05)$ dose-response trends were observed in the absence of S9 mix, except for the TA100 strain. The maximum dose of sediment equivalent per plate was approximately $0.04 \mu \mathrm{g}$ of $\mathrm{B}[a] \mathrm{P}$. This is 10 times less than the positive referenced value for mutagenic activity in TA98 and YG1041 with metabolic activation [29].

Our results are in accordance with other studies that also found negative results for reference areas [17,29]. However, soils and sediments in remote locations often have or indicate positive mutagenicity, making it hard to find adequate reference sites [30,31]. Furthermore, environmental matrices often induce significant dose-responses in the Salmonella/microsome assay, especially on the TA98 strain with and without exogenous metabolism $[30,32]$.

\subsection{Micronucleus Assay}

The micronucleus determinations for each 1000 hemocytes, with their respective means and standard deviations, in five specimens from each season sampling, are presented in Figure 2. The absence of results for autumn is because this is the period of molting or ecdysis, during which the crabs remain holed [33,34]. A statistically significant $(\mathrm{P} \leq 0.01$, ANOVA and Tukey) increase in the number of micronucleated cells was observed in summer compared to spring I and II.

The genotoxic damage observed in summer cannot be related to the analysis of mutagenesis in the sediment, since negative results were observed, but it may be discussed in conjunction with the PAHs characterization data. Fossi et al. (2000) [35] evaluated the micronucleus induction of hemocytes after exposure of the crab Carcinus aestuarii to $\mathrm{B}[a] \mathrm{P}$. They described positive results for values equal to or above $4 \mathrm{MN} / 1000$ hemocytes, and reported that $11 \mathrm{MN} / 1000$ hemocytes were found when the animals were exposed to $1.0 \mathrm{mg} \cdot \mathrm{Kg}^{-1} \mathrm{~B}[\mathrm{a}] \mathrm{P}$. Our data indicate a similar relationship, with $6.6 \mathrm{MN} / 1000$ hemocytes in summer, exactly the season in which 0.5 $\mathrm{mg} \cdot \mathrm{Kg}^{-1} \mathrm{~B}[a] \mathrm{P}$ was found in the sediment. This micronucleus frequency was just above ( $\mathrm{P} \leq 0.05$, null hypothesis test) the value reported as indicating positive genotoxicity [35].

\section{Conclusion}

Our data provide a basis for characterizing the metals and PAHs contents in sediments from Ilha Grande Bay, with the aim of enabling the effective management of the en-

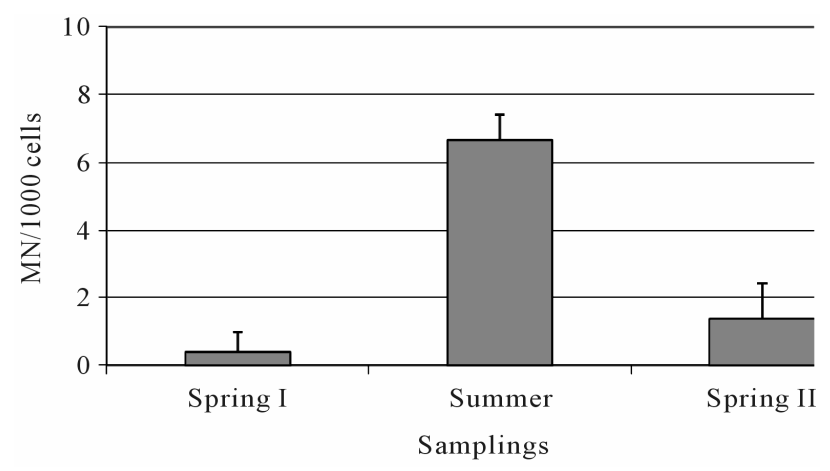

Figure 2. Micronucleus frequencies among the season samplings. 
vironment and related areas in response to the impact of human activities. Based on the results we suggest that the mangrove areas can still be considered susceptible to low or moderate contamination, which has resulted from the impact of the rapid expansion of economic and tourism activities in the surrounding regions. From a genetic toxicological viewpoint, the study sites seem to have been moderately polluted with $\mathrm{Cd}$ and $\mathrm{B}[a] \mathrm{P}$, which induce genotoxic damage. More stringent regulations by official agencies would help minimize and prevent the environmental impacts caused by human activity around the Saco do Mamanguá mangrove, thereby preserving this site and keeping it as a reference for non-contaminated mangroves.

\section{Acknowledgements}

We thank the Carlos Chagas Filho Foundation for Research Support of the State of Rio de Janeiro (FAPERJ), Coordination for the improvement of Higher Education Personnel (Capes) and National Council of Technological and Scientific Development (CNPq) for fellowships and financial support. We are greateful to Dr. Mônica Regina da Costa Marques from Institute of Chemistry/ UERJ for metal analysis. Special thanks to Center for Research on Mangroves (NEMA/UERJ) and to Rio de Janeiro Environmental State Institute (INEA/RJ).

\section{REFERENCES}

[1] J. F. Paixão, O. M. C. de Oliveira, J. M. L. Dominguez, E. S. Almeida, G. C. Carvalho and W. F. Magalhães, "Intregrated Assessment of Mangrove Sediments in the Camamu Bay (Bahia, Brazil)," Ecotoxicology and Environmental Safety, Vol. 74, No. 3, 2011, pp. 403-415. doi:10.1016/j.ecoenv.2010.10.038

[2] W. T. V. Machado, M. Moscatelli, L. G. Rezende and L. D. Lacerda, "Mercury, Zinc, and Copper Accumulation in Mangrove Sediments Surrounding a Large Landfill in Southeast Brazil," Environmental Pollution, Vol. 120, No. 2, 2002, pp. 455-461. doi:10.1016/S0269-7491(02)00108-2

[3] USEPA, 2010. http://water.epa.gov/polwaste/sediments/cs/contaminants. cfm

[4] M. A. Hortellani, J. E. S. Sarkis, D. M. S. Abessa and E. C. P. M. Sousa, "Assessment of Metallic Element Contamination in Sediments from the Santos-São Vicente Estuarine System," Quimica Nova, Vol. 31, No. 1, 2008, pp. 10-19. doi:10.1590/S0100-40422008000100003

[5] J. C. Pereira, A. K. Guimarães-Silva, H. A. N. Júnior, E. Pacheco-Silva and J. C. de Lena, "Distribution, Fractionation and Mobility of Trace Elements in Stream Sediments," Quimica Nova, Vol. 30, No. 5, 2007, pp. 1249-1255. doi:10.1590/S0100-40422007000500037

[6] M. F. Buchman, "NOAA Screening Quick Reference
Tables, NOAA ORR Report 08-1," Office of Response and Restoration Division, National Oceanic and Atmospheric Administration, Seattle, 2008.

[7] CONAMA, Brazil, National Environmental Council, Resolution Nr. 344, "Establishes General Guidelines and Procedures for Making Assessments of the Material to be Dredged in Brazilian Waters, and Other Measures," 2004.

[8] CONAMA, Brazil, National Environmental Council, Resolution Nr. 420, "Provides for Criteria and Guiding Values of Soil Quality for the Presence of Chemicals and Establishes Guidelines for Environmental Management of Areas Contaminated by These Substances Due to Human Activities," 2009.

[9] R. E. J. Juatinga, “Ecological Reserve,” 2011. http://www.inea.rj.gov.br/unidades/pqrej.asp

[10] B. N. Ames and L. S. Gold, "The Causes and Prevention of Cancer: Gaining Perspective," Environmental and Health Perspective, Vol. 105, No. 4, 1997, pp. 865-873.

[11] CONSEMA, Rio Grande do Sul State, Stadual Environmental Council, Resolution Nr. 129, "Provides for the Definition of Criteria and Standards for Emissions of Toxic Effluents Discharged into Surface Waters of the Rio Grande do Sul State," 2006.

[12] USEPA, US Environmental Protection Agency, "Prevention Pesticides and Toxic Substances. Health Effects Test Guidelines OPPTS870.5100 Bacterial Reverse Mutation Test," EPA 712-C-98-27, 1998.

[13] W. N. Choy, "Regulatory Genetic Toxicology Tests," In: W. N. Choy, Ed., Genetic Toxicology and Cancer Risk Assessment, Marcel Dekker, Inc., New York, 2001, pp. 93-113. doi:10.1201/9780203904237.ch5

[14] USEPA, US Environmental Protection Agency, "Methods for Collection, Storage and Manipulation of Sediments for Chemical and Toxicological Analyses: Technical Manual," EPA 823-B-01-002, 2001.

[15] L. P. Souza and J. R. F. Silva, "Morphology of the Female Reproductive System of the Red-Clawed Mangrove Tree Crab (Goniopsis cruentata Latreille, 1803)," Scientia Marine, Vol. 73, No. 3, 2009, pp. 527-539.

[16] E. D. Burton, I. R. Phillips and D. W. Hawker, "Geochemical Partitioning of Copper, Lead, and Zinc in Benthic, Estuarine Sediment Profiles," Journal of Environmental Quality, Vol. 34, No. 1, 2005, pp. 263-273. doi: $10.2134 /$ jeq2005.0263

[17] K. C. Tagliari, R. Cecchini, J. A. Rocha and V. M. F. Vargas, "Mutagenicity of Sediment and Biomarkers of Oxidative Stress in Fish from Aquatic Environments under the Influence of Tanneries," Mutation Research, Vol. 561, No. 1-2, 2004, pp. 101-117.

[18] M. Pueyo, G. Rauret, D. Luck, M. Yli-Halla, H. Muntau, P. Quevauviller and J. F. Lopez-Sanchez, "Certification of the Extractable Contents of $\mathrm{Cd}, \mathrm{Cr}, \mathrm{Cu}, \mathrm{Ni}, \mathrm{Pb}$ and $\mathrm{Zn}$ in a Freshwater Sediment Following a Collaboratively Tested and Optimised Three-Step Sequential Extraction Procedure," Journal of Environmental Monitoring, Vol. 3, 2001, pp. 243-250. doi:10.1039/b010235k

[19] N. Y. Kado, D. Langley and E. A. Eisenstadt, "A Simple 
Modification of the Salmonella Liquid Incubation Assay. Increased Sensitivity for Detecting Mutagens in Human Urine," Mutation Research, Vol. 121, No. 1, 1983, pp. 25-32. doi:10.1016/0165-7992(83)90082-9

[20] C. A. F. Aiub, L. F. Ribeiro-Pinto and I. Felzenszwalb, " $N$-Nitrosodiethylamine Mutagenicity at Low Concentrations," Toxicology Letters, Vol. 145, No. 1, 2003, pp. 36-45. doi:10.1016/S0378-4274(03)00263-7

[21] V. M. F. Vargas, V. E. P. Motta and J. A. P. Henriques, "Mutagenic Activity Detected by Ames Test in River Water under Influence of Petrochemical Industries," Mutation Research, Vol. 319, No. 1, 1993, pp. 31-45. doi:10.1016/0165-1218(93)90028-C

[22] A. H. Nudi, A. L. R. Wagener, E. Francioni, C. B. Sette, A. V. Sartori and A. L. Scofield, "Biomarkers of PAHs Exposure in Crabs Ucides cordatus: Laboratory Assay and Field Study," Environmental Research, Vol. 110, No. 2, 2010, pp. 137-145. doi:10.1016/j.envres.2009.10.014

[23] C. L. Teixeira, "Characterization of Surface Sediment from the Shores of the Bay of Ilha Grande, RJ, with Emphasis on Spatial Distribution of Metals," Dissertation, Universidade Federal Fluminense, Niterói, 2009.

[24] SedNet, "European Sediment Network," 2009. http://www.sednet.org/download/Sednet_booklet_final.pdf

[25] R. J. Donahoe and C. Liu, "Pore Water Geochemistry near the Water-Sediment Interface of a Zoned Freshwater Wetland in the Southeastern United States," Environmental Geology, Vol. 33, No. 2-3, 1998, pp. 143-153.

[26] B. B. Gueiros, W. Machado, S. D. L. Filho and L. D. Lacerda, "Manganese Behavior at the Sediment-Water Interface in a Mangrove Dominated Area in Sepetiba Bay, SE, Brazil," Journal of Coastal Research, Vol. 19, No. 3, 2003, pp. 550-559.

[27] F. Vincent-Hubert, A. Arini and C. Gourlay-Francé, "Early Genotoxic Effects in Gill Cells and Hemocytes of Dreissena polymorpha Exposed to Cadmium, and a Combination of $\mathrm{B}[a] \mathrm{P}$ and Cd," Mutation Research GTEM, Vol. 723, 2011, pp. 26-35. doi:10.1016/j.mrgentox.2011.031.008

[28] G. A. Umbuzeiro V. R. Coluci, J. G. Honório, R. Giro, D. A. Morales, A. S. G. Lage, J. L. Mazzei, I. Felzenszwalb, A. G. S. Filho, D. Stéfani and O. L. Alves, "Understand- ing the Interaction of Multi-Walled Carbon Nanotubes with Mutagenic Organic Pollutants Using Computational Modeling and Biological Experiments," Trends in Analytical Chemistry, Vol. 30, No. 3, 2011, pp. 437-446. doi:10.1016/j.trac.2010.11.013

[29] A. Aouadene, C. Di Giorgio, L. Sarrazin, X. Moreau, L. De Jong, F. Garcia, A. Thiery, A. Botta and M. De Méo, "Evaluation of the Genotoxicity of River Sediments from Industrialized and Unaffected Areas Using a Battery of Short-Term Bioassays," Environmental and Molecular Mutation, Vol. 49, No. 4, 2008, pp. 283-299. doi:10.1002/em.20384

[30] G. Chen and P. A. White, "The Mutagenic Hazards of Aquatic Sediments: A Review," Mutation Research, Vol. 567, No. 2-3, 2004, pp. 151-225. doi:10.1016/j.mrrev.2004.08.005

[31] F. M. R. da Silva Júnior and V. M. F. Vargas, "Using the Salmonella Assay to Delineate the Dispersion Routes of Mutagenic Compounds from Coal Wastes in Contaminated Soil," Mutation Research, Vol. 673, No. 2, 2009, pp. 116-123. doi:10.1016/j.mrgentox.2008.12.005

[32] S. Tabrez and M. Ahmad, "Mutagenicity of Industrial Wastewaters Collected from Two Different Stations in Northern India," Journal of Applied Toxicology, Vol. 31, No. 8, 2011, pp. 783-789.

[33] M. A. Igarashi, "Synopsis of the Current Situation, Prospects and Growing Conditions for Crawfish Palinuridae," Ciência Animal Brasileira, Vol. 8, 2007, pp. 155-166.

[34] N. F. O. Moura and P. A. Coelho, "Physiological Sexual Maturity in Goniopsis cruentata (Latreille) (Crustacea, Brachyura, Grapsidae) in the Estuary of Paripe, Pernambuco, Brazil," Revista Brasileira de Zoologia, Vol. 21, No. 4, 2004, pp. 1011-1015. doi:10.1590/S0101-81752004000400039

[35] M. C. Fossi, S. Casini, C. Savelli, C. Corbelli, E. Franchi, N. Mattei, J. C. Sanchez-Hernandez, I. Corsi, S. Bamber and M. H. Depledge, "Biomarker Responses at Different Levels of Biological Organization in Crabs (Carcinus aestuarii) Experimentally Exposed to $\operatorname{Benzo}(\alpha)$ pyrene," Chemosphere, Vol. 40, No. 8, 2000, pp. 861-874. doi:10.1016/S0045-6535(99)00300-8 